\title{
Conservation considerations for crowned pigeons, genus Goura
}

\author{
Catherine E. King and Joeke Nijboer
}

The three species of crowned pigeons are endemic to New Guinea and nearby islands where they are declining in numbers, especially near human settlements where hunting pressure is high. Little is known about their biology and ecology or about the magnitude of the impact of the threats from hunting, capture for trade, and loss of their lowland forest habitat. The authors make recommendations for action needed to secure the future for these large and attractive birds.

\section{Introduction}

The genus Goura, comprising three crowned pigeon species, can be considered 'one of the most remarkable evolutionary products of the long isolation of New Guinea's tropical humid forest' (Beehler, 1991). Despite their large size and their widespread distribution within New Guinea and nearby islands, to which they are endemic, very little is known about their biology and status in the wild (Beehler, 1991). The purpose of this article is to summarize what information is available concerning this group of birds, to discuss the potential threats facing it and to make recommendations for conservation action.

\section{Distribution and habitat}

Goura cristata, the western or blue crowned pigeon, inhabits lowland marshy and partly flooded forest areas from sea-level to $110 \mathrm{~m}$. Goura c. cristata occurs in north-western Irian Jaya east to Etna Bay in the south and to the Siriwo (Striwo/Sirowo) River in the north, while Goura c. minor is found on the islands of Misool, Salawati, Batanta and Waigeo (Rand and Gillard, 1968; Goodwin, 1983; Beehler et al., 1986) (Figure 1). Goura cristata has also recently been reported from Seram (Kitchener and Howard, 1991; Kitchener et al., 1993).

Goura scheepmakeri, the southern or maroonbreasted crowned pigeon, inhabits both dry and flooded forests from sea level to $500 \mathrm{~m} ; \mathrm{G}$. s. scheepmakeri occurs in south-eastern Papua New Guinea from Hall Sound to Orangerie Bay and Goura s. sclateri in southern Irian Jaya and Papua New Guinea between the Mimika and Fly Rivers (Rand and Gillard, 1968; Goodwin, 1983; Beehler et al., 1986). The range has not been clearly defined but apparently suitable habitat extends along the southern coast from Etna Bay to Orangerie Bay

Goura victoria, the Victoria crowned pigeon, inhabits flat, lowland and partly inundated tropical forests near sea level. Goura v. victoria is found on Yapen (Jobi) Island and Biak Island; it was possibly introduced to the latter. Goura v beccarii is found in northern Irian Jaya and Papua New Guinea between the head of Geelvink Bay (at Siriwo River) and Astrolabe Bay, and in the south-eastern Collingwood Bay region of Papua New Guinea between Holnicote Bay and Mount Maneao. It is said to hybridize with G. c. cristata in the Siriwo River region (Rand and Gillard, 1968; Goodwin, 1983; Beehler et al., 1986).

\section{Biology}

Although little information is available, the habits of the three Goura species appear to be similar: all reportedly travel in small parties of 2-10 birds, spending much time foraging on the ground, and all roost in trees (Rand and Gillard, 1968; Goodwin, 1983; Coates, 1985). 


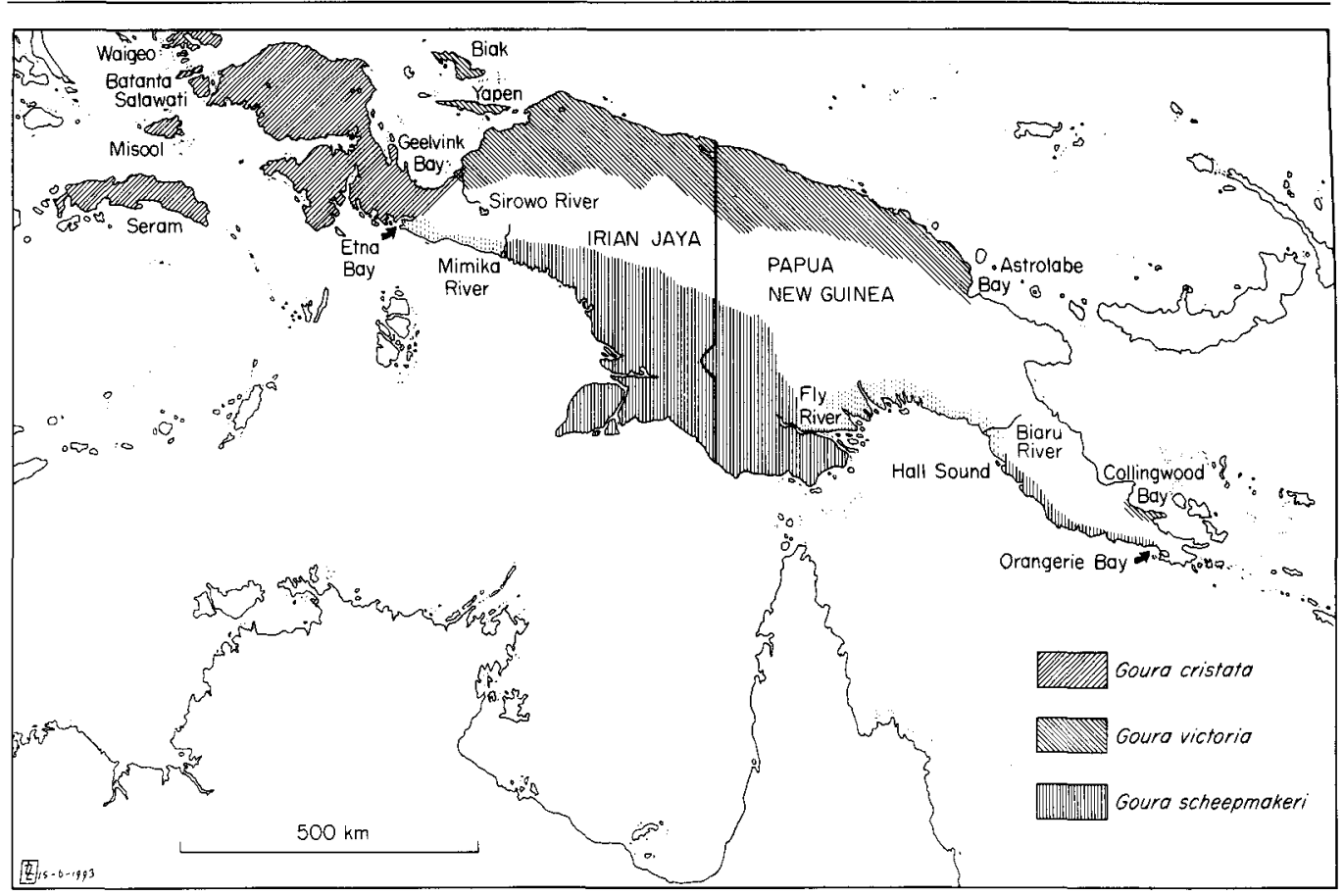

Figure 1. Map showing distribution of Goura spp. in New Guinea and associated islands.

Beehler (1991) suggested that crowned pigeons can be considered 'seed predators', and as such they tend to be erratic in their movements, wide ranging and have complex life histories.

In addition to the seeds, berries and fallen fruits typically consumed by crowned pigeons (Bell, 1970; Goodwin, 1983; Coates, 1985), G. scheepmakeri has also been observed feeding on small crabs (Grant [1915] cited in Goodwin, 1983). Crowned pigeons are also reportedly attracted to refuse at sago palm preparation sites (Beehler et al., 1986).

Nests are built in trees, and are neat, solid, compact structures. Recorded nests of $G$. scheepmakeri were composed of sticks and stems, palm leaves and tendrils and were located at heights between 3.5 and $15 \mathrm{~m}$ above ground (Rand [1942] cited in Goodwin, 1983; Coates, 1985). The age at which breeding starts has not been established; captive-reared crowned pigeons of both sexes have reproduced successfully when only 15-17 months old (Johst and Johst, 1961; Assink, 1988; Nijboer, undated). All three species lay one white egg, and the incubation period is $28-30$ days in captivity; incubation is shared by the male and female (Seth-Smith, 1931; Manfield, 1946; Fleay, 1961; Johst and Johst, 1961; C. King, J. Nijboer pers. obs.).

Both parents brood and feed the chick, which develops slowly. Young in captivity have been recorded leaving the nest at 28-36 days of age, at which time they are roughly one-third to one-half of adult size; full adult size is only reached after 3 months (SethSmith, 1931; Manfield, 1946; Fleay, 1961; Johst and Johst, 1961; C. King, J. Nijboer pers. obs.). Fleay (1961) reported that a captive-hatched, parent-reared $G$. victoria was entirely dependent on parental feeding for several months after leaving the nest, while Johst and Johst (1961) noted that a captive-hatched, parentreared G. cristata started feeding itself at 41 days, but that the male parent continued to feed it until it was 56 days old. The length of time that the parents feed young in captivity is probably determined by the rapidity with which they nest again. 


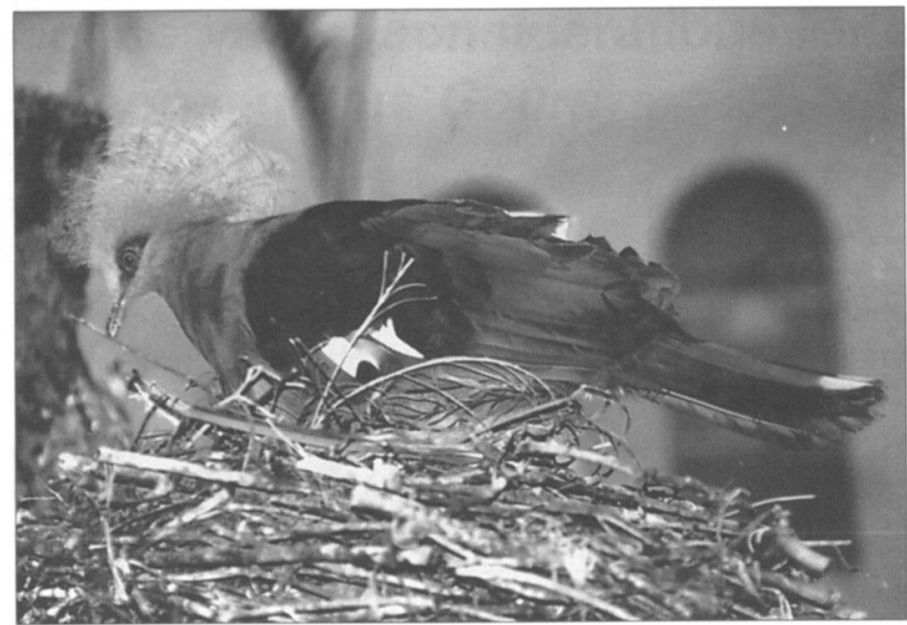

Goura cristata (Koen Brouwer).

\section{Population status, trends and current threats}

All three Goura spp. are considered 'rare' by IUCN (1990), and their future is uncertain (Beehler, 1991). There are no census data for any of the species, but some general observations on population trends are available.

Rand and Gillard (1968) noted that G. cristata is common in suitable habitat, but $\mathrm{K}$. Bishop (pers. comm., in Collar and Andrew, 1988) reported that it is being rapidly extirpated by hunting near villages. The one specimen collected from Seram had been caught by local villagers and was going to be eaten (Kitchener and Howard, 1991; Kitchener et al., 1993). Although J. Diamond (pers. comm., in Collar and Andrew, 1988) found that hunting pressure is less intense for this species than the others due to an unavailability of guns in much of its range, pressure for the bird trade appears high, as discussed below.

Goura scheepmakeri was originally considered 'fairly common to common' but is now very rare anywhere near human settlements (Rand and Gillard, 1968; Bell, 1969, 1970, 1982; Coates, 1985). It has already been hunted to extinction throughout much of its range in the south-east (Schodde, 1978; G. R. Kula, pers. comm., in Collar and Andrew, 1988). K. Bishop (pers. comm. in Collar and Andrew, 1988) found it to be still common in undisturbed forests on the Biau (Biaru) River in south-east Irian Jaya, but noted that it was shot indiscriminately there by police and military, and young were taken for pets.

Originally G. victoria was also considered to be 'fairly common to common' over much of its range, but it is now absent from large areas due to hunting pressure and is only numerous in remote areas (Coates, 1985). Rand and Gillard (1968) also noted that this species is usually extirpated near villages and towns. It is primarily killed for food, although its feathers are sometimes used for head-dresses (Coates, 1985).

Coates (1985) remarked that all three species were rapidly becoming quite rare because of hunting; all three species are hunted for food and plumes (Beehler, 1985; Nash, pers. comm. in IUCN, 1992), and are quickly eliminated by hunters from any forest within a day's walk of a village (Beehler, 1991). The role of indigenous people in the observed extirpation of crowned pigeons in human inhabited areas is unclear; M. Silvius (pers. comm.) remarked that crowned pigeon populations in some transmigration areas of Irian Jaya had remained healthy despite constant exploitation by native people, but were eliminated with the onslaught of the transmigration settlers.

Certainly, the disposition and behaviour of crowned pigeons make them particularly susceptible to hunting pressure. If disturbed, the birds prefer to walk or run away, but if forced to, will fly noisily to high branches where they 


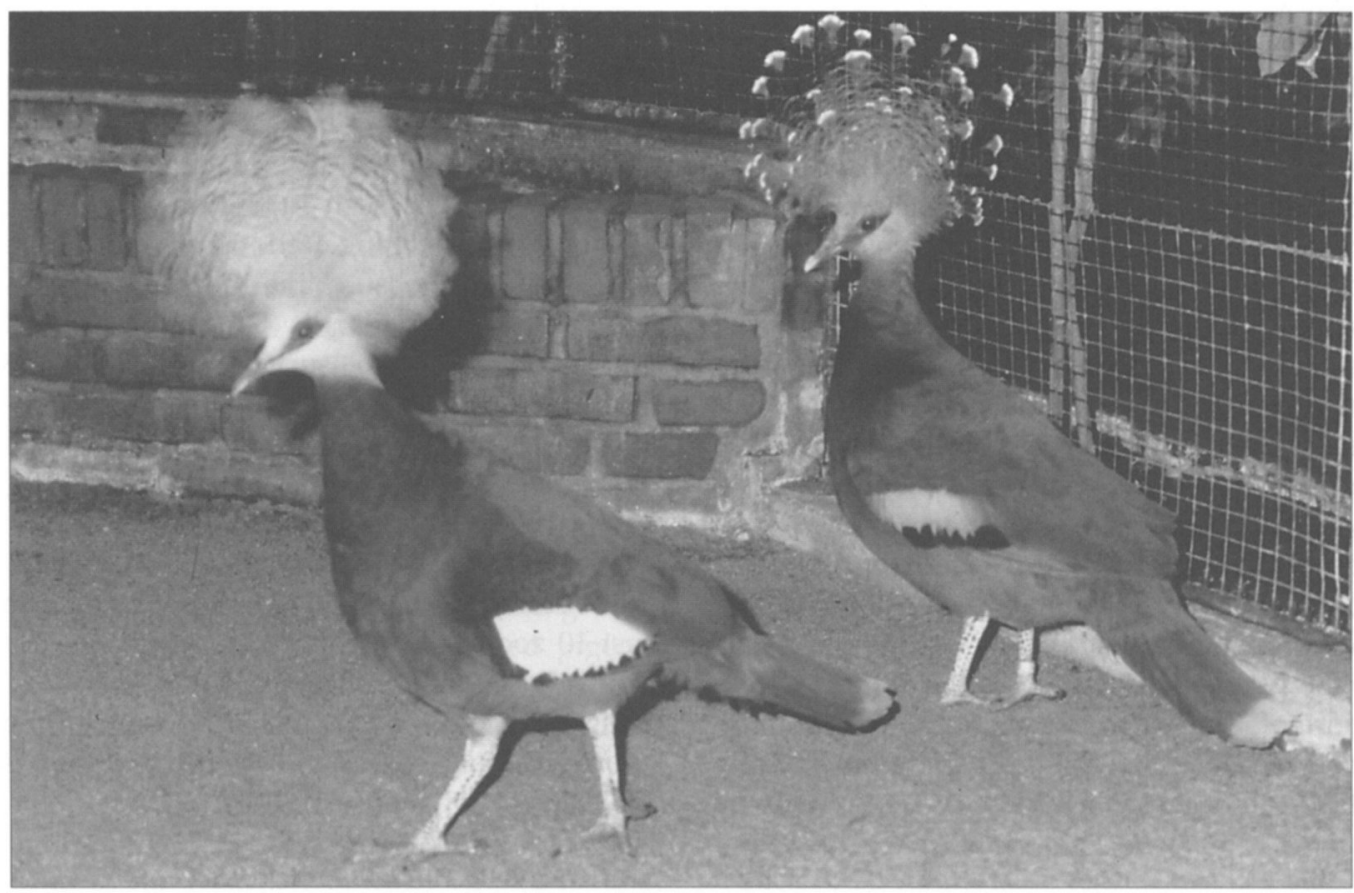

Goura scheepmakeri (left) and Goura victoria (Rotterdam Zoo).

'balance themselves clumsily and gawk at the intruder, making easy targets of themselves' (Rand and Gillard, 1968). Large congregations of $G$. cristata have been observed at waterholes in Irian Jaya where they can be easily netted (T. Cheng, pers. comm.). Nash (pers. comm. in IUCN, 1992) also reported that Goura tend to congregate in large numbers, and that this, together with their curiosity, renders them particularly susceptible to hunters. Bell (1967) remarked that $G$. scheepmakeri is said to be 'stupidly tame'.

\section{Trade}

Goura is protected from commercial trade and most domestic use within both Papua New Guinea and Irian Jaya (Shaw, 1968; Nichols et al., 1991). It is also listed on Appendix II of the Convention on International Trade in Endangered Species of Wild Flora and Fauna (CITES) and is listed on Annex C1 of the ECCITES regulation, which gives it the same status as a CITES Appendix I species in European Community countries. Despite protective national legislation, the Indonesian CITES authorities set an export quota of 200 specimens of $G$. s. sclateri from Merauke in 1992 (A. Bräutigam, pers. comm.).

Goura is highly prized as an aviary bird by bird parks, zoos and private aviculturists throughout the world (R. Wirth, pers. comm. in IUCN, 1992). They 'can be kept at liberty and look wonderful strutting around the garden' (Roles, 1991). Goura cristata has been identified as the subject of 'significant' levels of trade in the context of CITES by IUCN. However, insufficient information on actual trade levels and the paucity of status information preclude an assessment of the relative importance of trade for the conservation of this species (A. Bräutigam, pers. comm.).

An animal handler based in Singapore reported catching about 900 G. cristata in 1987 using nets at waterholes in Irian Jaya (Anon. pers. comm. to C. King); another large group of about 200 was seen during a visit to his 
farm in Singapore in June 1991 (C.King, pers. obs). He stated that he was holding another $c$. 100 specimens in Peninsular Malaysia, and that all the birds currently in his possession were captured 3 years previously (pers. comm. to C. King). Approximately 10 more G. cristata were seen at the farm of the only other bird dealer visited in Singapore during the same trip. Smaller numbers of G. scheepmakeri and G. victoria, a few dozens collectively, were also seen at these two facilities. The two dealers reported that they primarily sell crowned pigeons to East European countries and within South East Asia. All three species have been offered for sale in western Europe by a Czechoslovakian animal dealer in 1992 (R. Verkade, pers. comm.).

Singapore was named as the country of export of $72 \mathrm{G}$. cristata and $16 \mathrm{G}$. victoria imported into Switzerland for trade purposes in 1990. All of these 86 birds were reported to be captive-bred in Taiwan (Althaus and Irrall, 1991). T. Yaacob (pers. comm. to K. Brouwer) reported seeing approximately 600 crowned pigeons in Singapore between 1988 and 1989 at pet stores and bird dealer facilities. Four G. cristata were also seen in the only pet store visited during a June 1991 trip to Singapore (C. King, pers. obs.). Nine crowned pigeons were seen in Thailand's Bangkok weekend market during five surveys in 1987/1988 (Round, 1990). Although apparently not displayed at the bird markets in Jakarta, the birds are available 'upon request' (S. Walker, 1991; P. Widyabrata, pers. comm.).

Some 212 crowned pigeons (115 G. cristata, 29 G. scheepmakeri, 68 G. victoria) were held in just 10 zoos and a private aviary censused in South East Asia in 1990-91 (Yaacob, 1991; C. King, pers. obs.), and a mixed flock including more than 100 specimens of all three species collectively was observed in 1991 at Safari

Table 1. Live exports of Goura spp. by the primary exporter during the period of 1983 to 1988

\begin{tabular}{|c|c|c|c|c|c|c|c|c|}
\hline Goura spp. & Primary exporter & 1983 & 1984 & 1985 & 1986 & 1987 & 1988 & Average/year \\
\hline G. cristata & Canada & - & - & - & - & - & 1 & 0.2 \\
\hline G. cristata & Country unknown & - & 2 & - & - & 14 & 2 & 3.0 \\
\hline G. cristata & Germany (FDR) & - & - & - & 11 & - & - & 1.8 \\
\hline G. cristata & Indonesia & 70 & - & - & 1 & - & - & 11.8 \\
\hline G. cristata & Japan & - & 6 & - & - & - & - & 1.0 \\
\hline G. cristata & The Netherlands & - & 2 & - & - & - & - & 0.3 \\
\hline G. cristata & New Zealand & - & 2 & - & - & - & - & 0.3 \\
\hline G. cristata & Philippines & - & - & - & - & - & 2 & 0.3 \\
\hline G. cristata & Singapore & 22 & 3 & - & 4 & 12 & 22 & 10.5 \\
\hline G. cristata & Sri Lanka & 4 & - & - & 2 & - & - & 1.0 \\
\hline G. cristata & Taiwan & 16 & - & - & - & 300 & 60 & 62.7 \\
\hline G. cristata & Thailand & 4 & - & - & - & - & - & 0.7 \\
\hline G. scheepmakeri & Country unknown & - & - & - & 4 & 16 & 2 & 3.7 \\
\hline G. scheepmakeri & Germany (FDR) & - & - & - & 4 & - & - & 0.7 \\
\hline G. scheepmakeri & Singapore & - & - & 2 & 21 & - & 4 & 4.5 \\
\hline G. scheepmakeri & Taiwan & - & - & - & 4 & - & - & 0.7 \\
\hline G.s. sclateri & Switzerland & 1 & 1 & - & - & - & - & 0.3 \\
\hline G. victoria & Brazil & - & - & - & - & - & 2 & 0.3 \\
\hline G. victoria & Canada & - & 4 & - & - & - & - & 0.7 \\
\hline G. victoria & Country unknown & - & - & - & - & 2 & 3 & 0.8 \\
\hline G. victoria & Germany (FDR) & - & - & - & 4 & - & - & 0.7 \\
\hline G. victoria & Hong Kong & - & - & - & 1 & 1 & 1 & 0.5 \\
\hline G. victoria & The Netherlands & - & - & 2 & - & - & - & 0.3 \\
\hline G. victoria & Singapore & - & - & - & 9 & - & 29 & 6.3 \\
\hline G. victoria & Taiwan & - & - & - & 4 & - & - & 0.7 \\
\hline G. spp. & Singapore & - & - & - & 3 & - & - & 0.5 \\
\hline
\end{tabular}

Source: as reported to CITES (data processed by WCMC and provided by IUCN/SSC Trade Specialist Group). 
World, a private amusement/safari park outside Bangkok (R. Hoogenboom, pers. comm.; R. Wirth, pers. comm.). Another 47 crowned pigeons of unidentified species were seen in another three Indonesian zoos in 1990 (C. Zwart, pers. comm.).

The number of crowned pigeons exported by various countries (as primary exporter) and reported to CITES between 1983 and 1988 is shown in Table 1. Given the above information provided by an animal dealer and the large number of crowned pigeons in captivity in South East Asia, it would appear that the number of exports reported by Singapore to CITES during 1983-88 is lower than the number that were actually exported during those years. Although the $c$. 200 crowned pigeons seen in Singapore in June 1991 were said to be captured in 1988, and thus before the Singapore Endangered Species (import and export) Act of 1989, which enabled implementation of CITES (Anon., 1989), this is suspect. Due to the crowded housing conditions and suboptimal diet that these birds were receiving (C. King, pers. obs.), and the high turnover typical of the animal dealer business it would seem more probable that they are continually replaced by new specimens.

T. Inskipp (pers. comm. in IUCN, 1992) emphasized that because commercial trade of Goura is prohibited in both range countries and there is substantial evidence of international trade in apparently wild-collected specimens, illegal trade is obviously occurring. Large numbers of birds are rumoured to enter Europe illegally, for example 31 birds were confiscated in Spain in 1988 (L. Colom, pers. comm.).

Although international commercial trade for Goura plumes does not appear to be exten-

Table 2. The number of crowned pigeons in North American and European registered studbook populations as of 31 December 1990

\begin{tabular}{lllr}
\hline Species & $\begin{array}{l}\text { North } \\
\text { America }\end{array}$ & Europe & Total \\
\hline Goura cristata & 77 & 63 & 140 \\
Goura scheepmakeri & 13 & 23 & 26 \\
Goura victoria & 71 & 72 & 143 \\
\hline
\end{tabular}

sive, some 560 crowned pigeon heads, believed to have been collected some years ago, were confiscated from a feather handler in Amsterdam in 1991 (Anon., 1991). Most of the heads were dyed one of several colours, and could have been from either G. cristata or $G$. scheepmakeri (J. Nijboer, C. King pers. obs.).

\section{Captive management}

Management strategies for captive Goura populations are in varying stages of development. The South East Asian region does not have a studbook for this group of birds. Europe and North America have active studbooks, and there are plans to undertake a similar effort in Australia. A crowned pigeon European Endangered Species Programme (EEP) is also in effect (Assink, 1988; Nijboer, undated) and the studbook keeper in North America has recently petitioned for a similar Species Survival Plan (SSP) to be undertaken within North America (Wetzel, 1990). Wetzel is also studbook keeper for a recognized international studbook. Registered studbook populations in North America and Europe, as of 31 December 1990 (D. Wetze, pers. comm.; Nijboer, 1991) are shown in Table 2.

There are 53 zoos and private individuals participating in the North American studbook (Wetzel, undated b), and 33 (mostly Western) European facilities participating in the European one. Unregistered crowned pigeons are known to exist in both regions, for example some 70 unregistered specimens have been located in Europe (pers. comms to J. Nijboer). Unfortunately, little information on captive specimens, other than that presented here, is available from most areas of the world, including South East Asia and Eastern Europe, the regions expected to hold the most specimens. It is believed that many more birds are held in the private sector throughout these regions.

Captive breeding does not, and in the near future cannot, supply the demand for crowned pigeons as aviary birds, because breeding success in captivity is quite limited. The North American and European studbook 
populations have collectively suffered a negative population growth, with 156 deaths and 123 births, in the last 3 years for which data are available (1988-90) (Nijboer, undated, 1991; Wetzel, undated a, b, pers. comm.). Results in South East Asia are similar; seven births and five deaths were reported for a total population of 186 birds in 1990 (Yaacob, 1991). Much effort is currently being invested into developing techniques to improve breeding success, but this will take time.

\section{Future outlook and recommendations}

Theoretically, there should be sufficient crowned pigeon habitat for some time to come. Collins et al. (1991) found that 'about $86 \%(345,360 \mathrm{sq} \mathrm{km})$ of Irian Jaya remains forested and relatively undisturbed'. Nash (pers. comm. in IUCN, 1992) reported that the Protected Areas System in Irian Jaya includes 20 per cent of the land area of this Indonesian province, and watershed protection forests cover an additional 23 per cent. Although in theory these classifications should protect sufficient habitat for Goura in Irian Jaya, it is possible that these areas will be opened to exploitation (IUCN, 1992).

The human population in Papua New Guinea is now expanding with an annual net reproduction rate of 2.5 per cent, and the rate of forest resource use is also increasing (Jenkins, 1991; Saulei, 1991). Although some 78 per cent ( 36.2 million ha) of the total land area of Papua New Guinea (46.9 million ha) is covered with some type of forest, 52 per cent of this total forested area is considered inaccessible and it is the lowland forests areas that are being developed (Saulei, 1991). Beehler (1991) stated that large tracts of such forests unvisited by hunters are needed to protect crowned pigeons, but these are often high on the priority list for timber extraction, and no single large tract of lowland alluvial forest is formally protected in Papua New Guinea.

In reality, currently only some 2 per cent of the total area of Papua New Guinea is now protected, although a number of proposals have been made that can potentially increase this to 20 per cent (Saulei, 1991). However there is an increasing political pressure for resource development within Papua New Guinea, and this is occurring without vigorous monitoring of logging operations, adequate selection procedures for developers or implementation of the various Forestry and Environmental Acts that regulate resource development and protection (Saulei, 1991). A forestry bill passed in July 1991 extends the rights of traditional landowners in determining terms and conditions of resource development (TRAFFIC Oceania, 1991); it remains to be seen if, and how, this will alter forestry practices.

Obviously habitat depletion, domestic utilization and commercial trade all pose serious threats to Goura, and measures to protect the crowned pigeon group have not been entirely effective. Given the dearth of information concerning the biology and status of these birds, it is difficult to take steps to strengthen protection measures. For example, a proposal to upgrade Goura from CITES Appendix II to Appendix I in 1992 was withdrawn because of lack of population status information (C. Schuurman, pers. comm.).

Basic research and protection for Goura spp. are considered as priorities by the Papua New Guinea Department of Environment and Conservation (Morren, 1991), and indeed possibilities for research are increasing. A National Forest Action Plan is being developed, involving a partnership between landowners, government, World Bank, national and international non-governmental organizations and donor agencies. Some biological research can be carried out within the structure of this plan (Douglas, 1991; Petaulo, 1991). Wildlife Conservation International has set up the Wildlife Conservation International PNG Student Fund to which donations can be made to support student conservation research projects in Papua New Guinea.

As in Papua New Guinea, Indonesia has a network of non-governmental organizations that provide logistic and financial support to the wildlife/conservation governmental office of the Directorate General of Forest Protection and Nature Conservation (PHPA). The Asian 
Wetland Bureau has been working closely with PHPA in co-ordinating and conducting research activities as well as training national professionals. BirdLife International and World Wide Fund for Nature both have Indonesian programmes.

Population surveys and natural history studies for Goura are essential to develop and implement long-term strategies for its protection. Beehler (1991) noted that the studies should be conducted at considerable distances from any villages because of Goura's vulnerability to hunters. A. Bräutigam (pers. comm.) suggested that surveys of $G$. cristata are most urgent, because this species has the most limited range of the three. Protection of sufficient lowland forest habitat for crowned pigeons and utilization of these birds at sustainable levels is obviously essential to ensure their continued survival.

Parties to CITES could address, at least in part, problems associated with international trade in Goura by improving enforcement of CITES regulations. Particular attention should be paid to large shipments of purportedly captive-bred specimens (IUCN, 1992).

Proposed conservation initiatives suggested for Papua New Guinea from the perspective of the Papua New Guinea Department of Environment and Conservation include local education and participation of local people in conservation planning, training of national conservation professionals, basic research on biodiversity and related mechanisms in tropical rain forests, exploration of alternative exploitation of forest resources, and information management. These efforts could benefit Goura, and international support of these initiatives should given.

It is to be hoped that this article helps to stimulate research initiatives for acquiring the biological and status information needed to ensure the continued existence of the Goura group. It would be tragic if this unique group of birds went extinct before the seriousness of its plight was recognized.

\section{Acknowledgments}

We would like to thank our institution, Rotterdam
Zoo, for support in preparation of this article, the various persons mentioned throughout the article for supplying information, and A. Bräutigam, $\mathrm{K}$. Brouwer, A. Krefeld and R. Wirth for comments on the manuscript. Gratitude is also extended to Leon Zuydgeest, Rotterdam Zoo, for drawing the distribution map.

\section{References}

Althaus, T. and Irrall, B. 1991. Annual Report to the International Secretariat on the Management of the Convention on International Trade in Endangered Species of Wild Fauna and Flora 1990. Swiss Federal Veterinary Office, Liebefeld-Berne.

Anon. 1989. New CITES law in Singapore. Traffic Bull. 10 (3/4), 29.

Anon. 1991. Grote partij veren van beschermde vogels ontdekt bij handelaar. De Volkskrant, 13 February, 3.

Assink, H. 1988. The Crowned Pigeon Studbook Number 1. Rotterdam Zoo, Rotterdam.

Beehler, B. 1985. Conservation of New Guinea rainforest birds. In Conservation of Tropical Forest Birds (eds. A. W. Diamond and T. E. Lovejoy), pp. 233-247. ICBP Technical Publication No. 4. International Council for Bird Preservation, Cambridge.

Beehler, B. 1991. Papua New Guinea's wildlife and environments: what we don't yet know. In Conservation and Environment in Papua New Guinea: Establishing Research Priorities (eds M. Pearl, B. Beehler and M. Taylor), pp. 1-10. Wildlife Conservation International, New York.

Beehler, B.M., Pratt, T.K. and Zimmerman, D.A. 1986. Birds of New Guinea. Princeton University Press, Princeton.

Bell, E.H. 1967. Bird life of the Balimo sub-district, Papua. Emu, 67, 57-79.

Bell, H.L. 1969. Field notes on the birds of the OK Tedi River drainage, Papua. Emu, 69, 193-211.

Bell, H.L. 1970. Field notes on the birds of the Nomad River sub-district, Papua. Emu, 70, 97-104.

Bell, L.H. 1982. Birds in New Guinea rainforest. Emu, 82, 24-41.

Coates, B.J. 1985. The Birds of Papua New Guinea including the Bismark Archipelago and Bouganville, Vol. I. Dove Publications, Alderly, Queensland.

Collar, N.J. and Andrew, P. 1988. Birds to Watch, the ICBP World Checklist of Threatened Birds. ICBP Technical Publication No. 8. Smithsonian Institution Press, Washington, DC.

Collins, N.M., Sayer, J.A. and Whitmore, T.C. 1991. The Conservation Atlas of Tropical Forests: Asia and the Pacific. Macmillan, London.

Douglas, J. 1991. Coordination of international re- 
search. In Conservation and Environment in Papua New Guinea: Establishing Research Priorities (eds. M. Pearl, B. Beehler and M. Taylor), pp. 125-128. Wildlife Conservation International, New York.

Fleay, D. 1961. Gouras of New Guinea. Animal Kingdom, 64 (4), 106-110.

Goodwin, D. 1983. Pigeons and Doves of the World, 3rd edn. Cornell University Press, Ithaca.

Grant, C.H.B. in Ogilvie-Grant, W.R. 1915. Report on the birds collected by the British Ornithologists' Union Expedition and the Woollaston Expedition in Dutch New Guinea. Ibis, Jubilee Supplement, 2, 316-318.

IUCN. 1990. 1990 IUCN Red List of Threatened Animals. IUCN-The World Conservation Union, Gland.

IUCN. 1992. Analyses of Proposals to Amend the CITES Appendices. Prepared by IUCN/SSC Trade Specialist Group, World Conservation Monitoring Centre, and the TRAFFIC Network for the Eighth Meeting of the Conference of the Parties. IUCNThe World Conservation Union, Gland.

Jenkins, C. 1991. Environmental change and human health in Papua New Guinea. In Conservation and Environment in Papua New Guinea: Establishing Research Priorities (eds M. Pearl, B. Beehler and M. Taylor), pp. 75-82. Wildlife Conservation International, New York.

Johst, G. and Johst, E. 1961. Uber verhalten und brutpflege gekäfigter krontauben. J. Orn. 102, 88-96.

Kitchener, A. and Howard, P. 1991. Seram bandicoot project 1991. 79th Annual Report. Royal Zoological Society of London, Edinburgh.

Kitchener, A., MacDonald, A.A. and Howard, P. 1993. First record of the blue crowned pigeon on Seram. Bull. BOC 113, 43-43.

Manfield, H. 1946. The breeding in captivity of the crowned pigeon (Goura victoria) in the Adelaide Royal Zoological Gardens, South Australia. Avic. Magazine, 52 (6), 199-200.

Morren, G. 1991. Synthesis and preliminary action plan: conservation and environment in Papua New Guinea: establishing priorities. In Conservation and Environment in Papua New Guinea: Establishing Research Priorities (eds M. Pearl, B. Beehler and M. Taylor), pp. 136-141. Wildlife Conservation International, New York.

Nichols, D.G., Fuller, K.S., McShane-Caluzi, E. and Klerner-Eckenrode, E. 1991. Wildlife Trade Laws of Asia and Oceania. Traffic USA/Worldwide Fund, Washington DC.

Nijboer, J. 1991. Crowned Pigeons (Goura cristata, G. scheepmakeri and G. victoria). In EEP Yearbook 1990, with Summaries of Contributions and Discussions of the 8th EEP Conference, Budapest 12-15 May 1991 (eds K. Brouwer, S. Smits, and L. E. M. de Boer), pp. 31-34. EEP Executive Office, Amsterdam.

Nijboer, J. undated. Crowned Pigeon Studbook 2, 1989 Annual Report. Rotterdam Zoo, Rotterdam.

Petaulo, B. 1991. The National Forest Action Plan for PNG: linking landowners, non-governmental organizations, the government, and donor agencies. In Conservation and Environment in Papua New Guinea: Establishing Research Priorities (eds M. Pearl, B. Beehler and M. Taylor), pp. 129-135. Wildlife Conservation International, New York.

Rand, A.L. 1942. Results of the Archbold Expedition No. 42. Bull Amer. Mus. Nat. Hist.. 69, 289-377.

Rand, A.L. and Gillard, E.T. 1968. Handbook of New Guinea Birds. Natural History Press. Garden City.

Roles, D.G., 1991. Good ground dwellers for cage and aviary. AFA Watchbird, 18 (1), 30-32, 46-48.

Round, P.D. 1990. Bangkok Bird Club survey of the bird and mammal trade in the Bangkok Weekend Market. Nat. Hist. Bull. Siam Nat. Soc. 38, 1-43.

Saulei, S. 1991. Forest use and conservation in Papua New Guinea. In Conservation and Environment in Papua New Guinea: Establishing Research Priorities (eds M. Pearl, B. Beehler and M. Taylor), pp. 83-92. Wildlife Conservation International, New York.

Schodde, R. 1978. The status of endangered Papuasian. In The Status of Endangered Australasian Wildlife (ed. M. J. Tyler). pp. 133-145. Royal Zoological Society of South Australia, Adelaide.

Seth-Smith, D. 1931. The breeding of the crowned pigeon. Avic. Magazine, 4th Series IX, 20-21.

Shaw, D.E. 1968. Conservation ordinances in Papua New Guinea. Biological Conservation, 2, 51-61.

TRAFFIC Oceania. 1991. New Forestry Act in Papua New Guinea. Traffic Bull. 12 (3), 68.

Walker, S. 1991. The animal market in Jakarta ...as bad as it sounds. IPPL Newsletter, 18 (2), 7-9.

Wetzel, D. undated a. Crowned Pigeon Studbook, 1987-1988. Kansas City Zoological Gardens, Kansas City.

Wetzel, D. undated b. Crowned Pigeon Studbook, 1988-1989. Kansas City Zoological Gardens, Kansas City.

Wetzel, D. 1990. Crowned Pigeon SSP Petition. Unpubl. rept.

Yaacob, T.M.N. 1991. Association of Southeast Asian Zoos Census 1990. Zoo Negara, Ampang.

Catherine E. King and Joeke Nijboer, Royal Rotterdam Zoological and Botanical Gardens, Van Aerssenlaan 49,3039 KE Rotterdam, The Netherlands. 